\title{
Fonctions des pots, fonction des femmes
}

\section{Marie-Claude Mahias}

\section{OpenEdition}

Journals

Édition électronique

URL : https://journals.openedition.org/tc/779

DOI : $10.4000 /$ tc. 779

ISSN : 1952-420X

\section{Éditeur}

Éditions de l'EHESS

\section{Édition imprimée}

Date de publication : 1 octobre 1990

ISSN : 0248-6016

\section{Référence électronique}

Marie-Claude Mahias, «Fonctions des pots, fonction des femmes », Techniques \& Culture [En ligne], 14 | 1990, mis en ligne le 16 janvier 2006, consulté le 29 septembre 2022. URL : http://

journals.openedition.org/tc/779; DOI : https://doi.org/10.4000/tc.779

Ce document a été généré automatiquement le 29 septembre 2022.

Tous droits réservés 
Fonctions des pots, fonction des femmes

\author{
Marie-Claude Mahias
}

